\title{
Girişimcilik Yönelimi ve Finansal Performans İlişkisinin Araştırılmasında Aile Şirketlerinin Moderatör Rolü
}

\author{
Melissa CAGLE*
}

Ahmet ÖZEN**

\begin{abstract}
$\ddot{O} Z$
Bu çalışmada ülkemizdeki işletmelerin \%95'ini oluşturan aile şirketlerinin "girişimcilik derecesi - finansal performans" ilişkisini düzenleyici etkisi incelenecektir. Uluslararası literatürde aile şirketlerinin inovasyon ve değişimi destekleyen bir yapısı olduğu savunulmaktadır. Benzer şekilde, aile şirketi olmayan kurumlar ile karşılaştırıldığında, bu şirketlerin girişsimciliği teşvik ettiğ $i$ ve hızlı karar alma, büyüyebilme potansiyeli açısından ön plana çıtıtı̆̆ görülmektedir. Örgütsel başarının kilit bir bileşeni olarak tanımlanan girişimcilik yöneliminin, şirket finansal performansına olumlu yansımaları olduğu ve yüksek performans doğurduğu da ayrıca ileri sürülmektedir. Ülke ekonomisine katkıs yadsınamaz bir gerçek olan bu şirketlerin faaliyetlerini geliştirmek, iş sürekliliklerini korumak Türkiye açısından büyük bir önem taşımaktadır. Dolayısı ile son dönemlerde şirketlerin rekabet edebilirliğini ve girişimcilik özelliklerini gelişsirmek adina düzenlenen çeşitli politika ve programların artışı bu şirketleri yakından ilgilendirmekte. Ayrıca, bu durum Türkiye'nin konuya verdiği önemi desteklemektedir. Bu çalışmanın amacı BİST İmalat Sektöründe faaliyet gösteren şirketlerin ortaklı yapısını dikkate alarak girişimcilik yönelimini ampirik olarak test etmek ve şirket performanst üzerine etkisini incelemektedir. Örneklem 2018 yllında İmalat Sektöründe kote edilmiş 94 adet şirketi kapsaylp, ylllı finansal raporlardan toplanan verinin test edilmesinde Moderatör Çoklu Regresyon yönteminden yararlanılmaktadır. Çalışma sonucunda girişimcilik

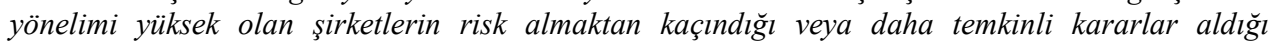
söylenebilir.
\end{abstract}

Anahtar Kelimeler: Aile Şirketi, Finansal Performans, BíST, Moderatör İlişki, Girişimcilik Yönelimi

JEL Sinıflandirması: M1, M4, M41, L26

\section{The Moderating Effect of Family Ownership on Entrepreneurial Orientation and Firm Performance}

\begin{abstract}
This study eximines the moderating effect of family owned companies, which constitutes 95\% of all Turkish enterprises, and its corresponding effect on the relationship between entrepreneurial orientation and financial performance. Family owned companies not only contain an organizational structure that supports innovation and change, but they are also known to encourage entrepreneurship. Moreover, these firms stand out in terms of their rapid decision making and growth potential. The related literature also suggests that entrepreneurial orientation, which is defined as a key component of organizational success, has a positive impact on the company's financial performance. The contribution of family owned companies to the economy is an undeniable fact, thus the improved continuity of their operations is key for maintaining the Turkish success. The rise of
\end{abstract}

\footnotetext{
* Dr., Dokuz Eylül Üniversitesi, İşletme Fakültesi, İşletme Bölümü. Email: melissa.cagle@ deu.edu.tr ORCID bilgisi: 0000-0003-0480-5626

** Prof. Dr., Dokuz Eylül Üniversitesi, İktisadi İdari Bilimler Fakültesi, Maliye Bölümü. Email: ahmet.ozen@deu.edu.tr ORCID bilgisi: 0000-0002-3251-3236
} 
various policies and programs aiming to develop companies' competitiveness and entrepreneurial characteristic closely concerns these firms- further highlighting the importance Turkish firms attach towards entrepreneurship. The purpose of this study is to take into account the BIST Manufacturing Sector firms partnership structure and empirically calculate the entrepreneurial orientation, while examining the effect on firm performance. The sample consists of 94 companies listed in the Manufacturing Sector in 2018, and the data collected from annual reports were tested employing use of a moderated multiple regression. The results of the study indicate that firms with high entrepreneurship orientation avoid risk and form more cautious decisions.

Key Words: Family Owned Company, Financial Performance, BIST, Moderator Relationship, Entrepreneurship Orientation

JEL Classification: M1, M4, M41, L26

\section{GİRIŞ}

Kavram olarak şirket; birden fazla gerçek veya tüzel kişiliğin emek veya sermayelerini ortak bir amaç doğrultusunda ve yasal bir sözleşmeye bağl1 kalacak şekilde birleştirmeleriyle oluşturulmuş ticari bir ortaklık şeklinde tanımlanabilir. $\mathrm{Bu}$ tür bir ortaklığın aralarında evlilik veya kan bağı bulunan "kadın, erkek, çocuk ve kardeşlerin oluşturduğu ve toplum içindeki en küçük bütün şeklinde tanımlanabilen aile bünyesinde bulunması" halinde aile şirketinden söz edilir. Genel olarak aile şirketi denildiğinde şirkete yönelik kararların çoğunlukla aile tarafından alındığ 1 ve yönetimin de yine bu topluluk tarafindan yürütüldüğü bir şirket türü anlaşılabilir. $\mathrm{Bu}$ genel tanıma karşın literatürde aile şirketi farklı açılardan ele alınmakta ve tanımlanabilmektedir. Örneğin, Salvato, vd. (2019), Minichilli, vd. (2016), Leach (1990) ve Donckels ve Fröhlich (1991) çalışmalarında şirketin halka açık bir şirket olması durumunda hisse senedi sahipliği ve karar almada oy hakkının bir ailede kaldığı şirket türünü aile şirketi olarak nitelendirmişlerdir. Diğer yandan Salvato, vd. (2019) çalışmalarında aile şirketinden söz edebilmek için şirket içi politika belirleyebilme gücünün de bir ailede olması gerektiğini vurgulamışlardır. Anderson ve Reeb (2003) ve Lee (2006) ele aldıkları çalışmalarında aile şirketinden söz edebilmek için aile üyelerinin yönetim kurulu içindeki üyelik durumlarına bakılması gerektiğini belirtmişlerdir. Akdoğan (2000), Karpuzoğlu (2004), Kobal (2014) ve Lee (2006) ise aile şirketlerinde ikinci nesile kadar belirli aile üyelerinin şirkette bulunduğunu ve kurucu üyenin şirkette varlığının devam ettiğini ifade emişlerdir. Öte yandan Church (1969) aile şirketini sermayenin tamamının tek kişinin elinde olduğu dolayısıyla halka açık bir şirket niteliği taşımadığını ifade etmiştir. Elbette günümüzde bu tanım dar kapsamlı kalmıştır. Dolayısı ile, halka açık şirketlerin de aile şirketi niteliklerini koruyabildikleri rahatlıkla belirtilebilir.

Dünyada aile şirketlerinin ülke ekonomilerine katk1 düzeyleri incelendiğinde; sanılanın aksine aile şirketlerinin ülke ekonomileri açısından yadsınamayacak düzeyde itici bir güç bulunmaktadır. Elbette bu yönde çeşitli akademik çalışmalar da bulunmaktadır. Örneğin Akdoğan (2000) aile şirketlerinin en yaygın işletme türlerinden biri olduğunu ve yarattıkları katma değer bakımından etkinliklerinin tartışılmaz derecede olduğunu vurgulamıştır. Miller (2015) ise aile şirketlerinin birçok ülkede GSYIH'nın dörtte üçünü ürettiklerini ve Fortune Global 500'deki şirketlerin beşte biri de dahil olmak üzere, dünyanın serbest 
ekonomisindeki işletmelerin \%80'inden fazlasının aile şirketi olduğunu açıklamıştır. Diğer yandan Galván, vd. (2017)'de çalışmalarında aile şirketlerinin dünyadaki birçok ekonominin bel kemiği olduğunu; $\mathrm{ABD}$ ve Kanada'daki tüm işletmelerin yaklaşık \%90'ının aile şirketi niteliği taşıdığının tahmin edildiğini belirtmişlerdir. Son olarak, Minichilli, vd. (2016) de günümüzde aile tarafından kontrol edilen firmaların dünyadaki baskın ekonomik ve sosyal gücü temsil ettiğini açıklamışlardır.

Aile şirketlerinin Türkiye'deki mevcut durumu ve milli ekonomimize katkıları ele alındığı taktirde; ülkemizdeki işletmelerin yaklaşık \%95'inin (Sabanc1, 2017) aile şirketi hüviyetinde olduğu ve dolayısıyla milli ekonomimize göz ardı edilemez düzeyde katkılarının olduğu söylenebilir. Örneğin, Deloitte Türkiye Yönetim Kurulu Danışmanı Uzun (2018), konuya ilişkin sunumlarında aile şirketlerinin $\% 52$ 'sinin üretim, \%16'sının inşaat ve emlak geliştirme, \%6'sının tüketici ürünleri gibi ülkemiz ekonomisi için önemli alanlarda faaliyet gösterdiğini açıklamıştır. Yolaç ve Doğan (2011) çalışmalarında aile şirketlerinin dünya ekonomindeki oransal büyüklüğüne benzer olarak ülkemiz açısından da önemli olduğunu ve bu şirketlerin pek çok akademik araştırmaya da konu olduklarını belirtmişlerdir. Köylü (2018) ve Ateş (2005) de nesilden nesile geçerek günümüze ulaşan aile şirketlerinin sınırlı kaldığını, buna karşın bu şirketlere olan güvenin ve çalışan iş doyumunun (çalışma ortamlarındaki memnuniyet düzeylerinin) de yüksek olduğu sonucuna varmışlardır. Ayrıca şirketin kurucu ailesinin çalışanlarıyla yakın ilişkide olmasının şirket çalışanlarına güven verdiğini, böylece aile şirketlerin daha güvenilir olduğunu ve şirket içi koordinasyon kolaylığı taşıdığını da açıklamışlardır. Elbette bu tür bir durumun varlığı şirketin geleceğe yönelik alacağı kararlarda, dolayısıyla girişimciliği üzerine de yansiyabilmektedir.

Aile şirketi olsun veya olmasın, bir şirketin girişimci olmasının o şirketin büyüme ve elbette performansında itici bir güç olma fonksiyonu bulunmaktadır. Nitekim Kuratko, vd. (2001) şirketlerin girişimcilik davranışlarının rekabet avantajı sağladığını ve firma performanslarını iyileştirdiğini savunmuşlardır. Girişimcilik faaliyetleri ise başka şirketlerin henüz fark etmediği firsatlardan yararlanıp, müşteri, pazar veya kaynaklar (veya kombinasyonu) açısından fark yaratma faaliyetleri şeklinde tanımlanmıştır. Kaya (2006) kurumsal girişimciliği bir şirketin inovasyon, girişim ve yenileme çabalarının toplamı olarak tanımlamış ve kurumsal girişimciliğin firma performansını etkilediğini belirtmiştir. Dess, vd. (1997) strateji oluşturmaya yönelik girişimci bir yaklaşımın örgütsel başarı için hayati öneme sahip olduğunu ve satış - kârlılık gibi beklentiler ile şirket performansı arasında pozitif bir ilişki olduğu tespit etmiştir. Dolaysıyla girişimcilik ve finansal performans arasında bir etkileşimin olduğu belirtilebilir. Peki aile şirketi niteliğinde olmanın girişimcilik ve finansal performans üzerinde nasil tesiri olabilir?

López-Fernández, vd. (2016) aile şirketlerinde aile bireylerinin girişimcilik ateşini besleyen oksijen olduğunu; Lee ve Scandura (2018) ise örgütün psikolojik sahipleri olarak aile üyelerinin örgütsel hedefleri izlediklerini ve 
örgütsel performans1 en üst düzeye çıkarmak için motive olduklarını vurgulamışlardır. Randolph ve Daspit (2017) mevcut organizasyonlarda inovasyon ve büyümeyi teşvik etmek amacıyla yapılan girişimcilik faaliyetlerinin güçlü bir şirket ve sürdürülebilir başarı için kritik öneme sahip olduğunu belirtmişlerdir. Ayrıca şirket başarısının temelinde aile firmasının karar alma konusunda ileriye dönük bir bakış açısı sergilemesinin ve şirket sürekliliğine önem vermesinin yattığını savunmuşlardır. Bettinelli, vd. (2017) aile şirketlerinin eş zamanlı olarak gelecekte parçası olabileceği iş alanlarını takip ettiğini ve üstün performans sergileyebileceği alanları belirlemeye çalıştığını ifade etmişlerdir. Ayrıca aile şirketlerinin diğer şirket türlerine nazaran daha başarılı olmasının nedenleri arasında yüksek organizasyonel esnekliğinin olmasının ve daha inovatif ürünler sunmalarının yer aldığını iddia etmişlerdir. Memili, vd. (2010) aile şirketleri başarılarının devamını sağlamak, gelecek nesillere geride bir şey bırakmak için rekabetçi bir performans sergilemek zorunda olduklarını ve girişimci risk almak zorunda olduklarını açıklamışlardır. Aile şirketlerinin nesiller boyu sürdürebilirlik ve firma performansını artırmak için girişimci olduklarını belirtmişlerdir. Salvato, vd. (2010) ise aile faktörünün sahip olduğu işletmeyi güçlü duygusal bağlarla geleceğe yönelik girişimcilik firsatlarını yakalamaya itebileceğini savunmuştur. Son olarak, Miller ve Le Breton-Miller (2011), aile fertlerinin girişimcilik davranışlarını şekillendirdiği gibi, şirketlerinin finansman sağladıkları kurumlardan da etkileneceği (üstün finansal performans ve büyüme elde etmek için) ve finansal başarı/büyüme elde etmek için cesur girişimcilik örnekleri sergileyeceklerini ifade etmiştir.

Konu ülkemiz açısından ele alındığında; Türk şirketlerinin özellikle de bazı holdinglerin diğer yabancı şirketler ile yarışabildiği (Bloomberg, 2018) ve şirketlerin başarısının sırrının aile şirketi olmalarından kaynakladığı söylenebilir (Hisarcıklığlu, 2019). Yani aile şirketleri; girişimcilik özellikleri ve uluslararası finansal başarıları ile dikkat çekmektedir. Acaba aile şirketi olmanın girişimci olma ve finansal performans başarısı üzerine rolü ne düzeydedir? Nitekim bu çalışmanın amaçlarından biri literatürde vurgulanan girişimcilik davranışları ve finansal şirket performansı arasındaki ilişkide aile şirketlerinin düzenleyici rolünü incelemektedir. Özellikle dünya ve Türkiye ekonomik gelişiminde de önemli bir rol oynayan bu şirketlerin girişimcilik davranışlarına artan ilgi bu çalışmayı yapmak için motivasyon yaratmaktadır.

Bununla birlikte çalışmanın diğer amacı ise karşılaştırılabilir ve daha objektif veriler yolu ile ölçülebilir bir girişimcilik yönelim modeli geliştirmektir. Öyle ki uluslararası literatürde yoğunlukla geçmekte olan girişimcilik yönelimi kavramının (Wales, vd. 2019) ölçümleri sübjektif tekniklere (Örnek olarak, anket) ve veriye dayanmaktadır (Lyon vd., 2000). Girişimciliğin heterojen yapıs1 uluslararası veya sektörler arası karşılaştırılabilirliği düşürmekte (Terjesen, vd. 2016) ve bu alanda yapılan çalışmaların güvenirliliğini azaltmaktadır. Benzer şekilde Lyon, vd. (2000), çok-boyutlu bir değişken olan girişimciliği görüşme yoluyla ölçmenin hatalı sonuçlar doğurabileceğini vurgulamıştır. 
Belirtilen amaçlara yönelik olarak çalışmada şu aşamalar takip edilecek ve bulgular elde edilmeye çalışlacaktır. İlgili literatürden girişimcilik yönelimi tanımlanıp, alt bileşenleri belirlenecektir. $\mathrm{Bu}$ bileşenlerin ampirik olarak ölçülebilmesi amacı ile literatürden desteklenerek teknikler ortaya konulacaktır. 2018 y 1 lında BİST İmalat Sanayiinde kote şirketlerin finansal tablolarından ampirik olarak hesaplanan "inovasyon, proaktiflik ve risk-alma" girişimcilik bileşenlerini oluşturacaktır. Uygulanacak Temel Bileşenler Analizi yardımı ile "Girişimcilik Yönelimi Endeksi" oluşturulacaktır. Şirketlerin girişimcilik davranışları ve finansal şirket performansı arasındaki ilişkide aile şirketlerinin düzenleyici rolünü incelemek amacıyla SPSS 23 programı ile Moderatörlü Çoklu Regresyon Analizi uygulanacaktır. Çalışma neticesinde girişimcilik yönelimine ilişkin yeni model ortaya konulmaya, şirket başarısını tetikleyen girişimciliğin şirket performansı üzerine etkisi tespit edilmeye çalışılacak ve aile şirketlerinin bu ilişkide düzenleyici rolünün olup olmadığı sorgulanacaktır.

Yapılan analiz sonucunda aile şirketlerinin mevcut ilişkide düzenleyici rolünün olmadığ1, ancak risk alma eğiliminin daha yüksek olduğu görülmüştür. Son olarak, BİST şirketlerde aile şirketi yapısının yoğunlukta olduğu tespit edilmiştir. Çalışmanın girişimcilik yönelimi literatüründeki katkısının olması beklenmektedir. Uygulanacak ampirik analiz ile mevcut genel metodolojik limitasyonlara alternatif önerilecektir. Çalışmanın amacı çerçevesinde bir sonraki bölümde girişimcilik ve performans ilişkisi aile şirketleri açısından incelenecektir. İkinci ve üçüncü bölümde modelin metodolojisi incelenecek ve son olarak, bulgular değerlendirilecektir.

\section{LITERATÜR TARAMASI}

1983 y1lında Miller tarafindan "inovasyon, proaktiflik ve risk-alma" boyutlarını içerecek şekilde öne sürülen "girişimcilik yönelimi”" kavramı, literatürde en çok üstüne uzlaşılmış ve sıklıkla kullanılan tanımı temsil etmektedir. Miller (1983) "ürün pazarında inovasyon yapan, riskli girişimlerde bulunan ve rakiplerini geçmek amacı ile proaktif atılımlarda bulunan” bir şirketi girişimci olarak tanımlamaktadır. Literatürde aile şirketlerinde girişimcilik davranışları incelendiğinde şirket performansı üzerinde önemli bir etkisi olduğu savunulmaktadır. Naldi vd. (2007) dünya ekonomisinde önemli bir yere sahip olan aile şirketlerinin girişimcilik davranışları - finansal performansı arasındaki ilişkinin yeterince araştırılmadığını savunmaktadır. İsveç’te aile şirketi olan/olmayan KOBİ'leri 1997-2000 yılları arasında, karşılaştırmalı olarak inceledikleri çalışmada girişimcilik yöneliminin şirket performansı üzerine etkisini anket ve telefon görüşmesi yolu ile ölçmüştür. Şirket yöneticilerine gönderdikleri ankette 265 aile şirketinden ve 431 aile olmayan şirketten veri toplanmıştır. Şirket finansal performansını değerlendirmek adına şirketin karlılığı, satış büyümesi, nakit akışı ve net değer artışı anket yoluyla toplanmıştır. Girişimcilik yöneliminin hesaplanması için ise Covin ve Slebin (1986; 1989)'un dokuz öğeli likert ölçeğinden yararlanılmıştır. Toplanan veri faktör analizi (EFA ve CFA) uygulanarak incelenmiştir. Analiz sonucunda aile şirketlerinde risk almanın girişimcilik yönelimi değerini yönlendiren önemli bir etken olduğu, proaktif ve 
inovasyon değişkenler arasında pozitif bir ilişkisi olduğu tespit edilmiştir. Ayrıca, aile şirketlerinin diğer şirketlere nazaran daha az risk aldığ 1 ve finansal performans başarısı - risk alma arasında negatif bir ilişki olduğu tespit edilmiştir. Yazarlara göre bu negatif ilişki, aile şirketlerinde risk almanın stratejik planlamaya dayandırılmamasından ve dış paydaş baskısı olmamasından kaynaklanmaktadır. Casillas ve Moreno (2010) İspanya'da faaliyet gösteren 449 aile şirketinin finansal performansı (örnek olarak; 4 yıllık karlılık ve büyüme oranı verisi) ve girişimcilik yönelimi arasındaki ilişkiyi incelemiştir. Anket ile toplanan değişkenler, likert ölçeğinde şirket çalışanlarına uygulanmıştır. Geliştirilen modeli hiyerarşik doğrusal regresyon analizi ile test eden çalışma, şirket yönetiminde ailenin aktif rol alması ile beraber inovatif faaliyetlerin şirket büyümesini olumlu etkilediğini, aksine risk-alımı ve proaktif davranışların büyümeyi olumsuz etkilediğini savunmaktadir.

Zellweger ve Sieger (2012) girişimci tutum ve davranışların bir şirketin kısa ve uzun vadeli başarısı için çok önemli olduğunu savunmaktadır. Girişimci bir yaklaşımın, belirsizlik ortamında şirketi yeni firsatlar aramaya iteceğini savunan Zellweger ve Sieger (2012), 80 - 175 y1l arasında faaliyet gösteren uzun ömürlü aile şirketlerini incelemiştir. Çalışma anket yolu ile İsviçre'de çalışan 14 yönetici üzerine uygulanmıştır. Anketten elde edilen sonuçlar doğrultusunda, yazarlar girişimci davranışlarının aile şirketi yapısı nedeniyle kısıtlandığını, ancak şirket yönetiminin bir jenerasyondan diğerine geçmesi ile faaliyetlerin içsel-inovasyondan dışsal-inovasyona (örnek olarak, yeni ürünlerin piyasaya sunulması) kaydığı gözlemlenmiştir. Aile şirketlerinin şirket geleceğini tehlikeye atacak risklerden kaçındığı ve dengeli yatırımlarda bulunduğu savunmaktadır. Ayrıca, finansal kaldıraç oranı incelendiğinde, aile şirketlerinin riskten kaçındığ ve "bekle ve gör" politikasını uygulayarak dönemsel olarak proaktif davranışlarını azalttığ 1 görülmüştür. Ancak, düşük risk-alımı ve proaktif davranışlarının şirket sürdürülebilirliğini ve performansını olumsuz etkilemediği savunulmuştur. Craig vd. (2014) Finlandiya'da gıda, medya ve gemi üretimi alanlarında faaliyet gösteren 532 şirketin girişimcilik yönelimini incelemiştir. Proaktiflik, risk-alma ve inovasyon değişkenlerinin aile şirketi olan/olmayan şirketlerde farklılık gösterdiğini belirtmiştir. Telefon görüşmesi yolu ile yapılan çalışmada proaktiflik ve risk-alımı verileri Covin ve Slevin (1989); Lumpkin ve Dess (2001)'in 6 maddeli ölçeği ile toplanmıştır. Örneklemin finansal performansı ise piyasaya sunulan yeni ürünün yarattığı toplam gelirin pay ölçütü (output) olarak hesaplanmıştır. Hiyerarşik lineer modelleme yolluyla test edilen veriler sonucunda, aile şirketi olan/olmayan şirketlerin performans çıktıları karşılaştırıldığında risk-alımı davranışların aile şirketi olmayan şirketlere olumlu yansıdığı görülmüştür. Aile şirketlerinin performansı ve risk-alımı davranışları arasında ise anlamlı bir ilişki tespit edilmemiştir. Dolayısı ile, Craig vd. (2014) aile şirketlerinin daha muhafazakâr olduğunu ve risk almaktan kaçındıklarını savunmuştur. Ayrıca, alınan riskler sonucunda örneklem şirketlerin finansal performansında bir düşüş gözlemlenmiştir. Proaktif davranışların aile şirketlerine etkisi incelendiğinde, aile şirketlerinin almış olduğu kararların finansal performansına olumlu yansıdığı 
savunulmuştur. Craig vd. (2014) bunun nedeninin aile şirketlerinde katı bir hiyerarşi ve bürokrasi olmamasına, dolayısı ile yeni projelere daha proaktif bir şekilde katılım sağlayabilmelerine bağlamıştır.

Wennberg vd. (2011) İsveç'te 10 y1llık (1997 - 2007 aras1) bir süre içerisinde el değiştirmiş tüm aile şirketlerin belirsizlik ortamında girişimcilik yönelimi ve bunun performans yansımaları incelenmiştir. 3280 adet şirketi inceleyen çalışma, finansal performans göstergesi olarak satışlarda büyüme ve EBİTA'yı devir öncesi ve sonrası olarak karşılaştırmıştır. Yapılan analiz sonucunda devredilen firmaların, aile şirketlerine nazaran daha iyi performans gösterdiği ancak, aile içinde kalan şirketlerin daha uzun dönemli faaliyet gösterdiği (5 y1l süreklilik) tespit edilmiştir. Şirketlerin kısa ve uzun dönemli performansını karşılaştırmalı olarak inceleyen Wennberg vd. (2011), aile şirketlerin uzun dönem stratejilerinin (long term orientation) girişimcilik faaliyetlerini yönlendirdiğini savunmaktadır. Sermaye yapısını ve şirket içi kontrol oranlarını stabil tutma uğraşı içerisinde olan aile şirketlerin borç almaktan ve yeni yatırım yapmaktan kaçındığ 1 tespit edilmiştir. Aksine, devredilen şirketlerin benzer endişeleri olmadığı ve daha girişimci davranabildiği savunulmuştur. Schepers vd. (2014) girişimcilik yönelimi literatürüne Sosyo-Duygusal Zenginlik (SDZ) olgusunu entegre ederek, aile şirketlerinde girişimcilik yönelimi ve finansal performans ilişkisini incelemiştir. Şirket kimliği, aile bireylerinin şirket içi baskı oranı, birkaç jenerasyonun aile içinde eş zamanlı rol alması gibi etkenleri inceleyen SDZ olgusunun girişimcilik davranışlarının olumlu finansal yansımasının şirketlerde azaldığını tespit etmiş̧ir. 2002-2003 yılları arasında Belçikada faaliyet gösteren 232 şirket yöneticisine anket göndererek, toplanan verileri lineer regresyon analizi uygulayarak inceleyen Schepers vd. (2014), girişimcilik yönelimi Covin ve Slevin 1991; Miller 1983 tarafindan geliştirilen ölçek yoluyla ve finansal performans ise varlık getirisi oranının hesaplanması ile bulunmuştur. Şirket içi uygulanan girişimcilik faaliyetlerinden beklenen faydanın sağlanmasını engellediği savunulan SDZ olgusunun, vekalet maliyetler nedeni ile aile şirketlerinde karlılı̆ıını düşürdüğünü savunmaktadır. Benzer şekilde Kallmuenzer vd. (2018) 180 aile şirketinde girişimcilik yönelimi davranışları ve finansal performans arasındaki ilişkiyi incelemiştir. Finansal performans göstergesi olarak satışlarda büyümeyi, satış getirisi, brüt kar ve net karı hesaplayan Kallmuenzer vd. (2018), ilgili veriyi anket yoluyla toplayarak faktör analizi uygulamıştır. SDZ davranışlarının şirket stratejisi ile uyumlu bir şekilde yönetilmesi gerektiğini savunan çalışma, başarılı olunduğu taktirde proaktif ve otonom aile şirketlerinin finansal performansının olumlu etkileneceğini savunmaktadır. Kallmuenzer vd. (2018), rakiplerini takip etmek yerine, yeni ürünler veya hizmetler sunan ve paydaşları tarafından kısıtlanmayan aile şirketlerinin başarılı olduğunu tespit etmiştir. Arzubiaga vd. (2018) ise İspanya'da faaliyet gösteren $230 \mathrm{KOBİ} \mathrm{aile} \mathrm{şirketin} \mathrm{girişimcilik} \mathrm{yönelimi} \mathrm{ve}$ finansal performansı arasındaki ilişki SDZ ve kaynak tabanlı yaklaşım açısından incelemiştir. Girişimcilik yönelimi (Covin and Slevin, 1989), kazanç getirisi oranı ve varlık getirisi oranı anket yoluyla toplanan çalışmada, aile üyelerinin şirket yönetimine katılımı ile girişimci davranışların finansal performans üzerine olumlu 
yansımaları olduğu savunulmaktadır. Ek olarak, yönetim kurulunda kadınların ağılıklı olmasının katılımın, aile KOBİ'lerinde firma performansı üzerindeki olumlu etkisini güçlendirdiğini tespit etmiştir.

Peters ve Kallmuenzer (2018), Avusturya'da turizm alanında faaliyet gösteren 17 şirket sahibinin girişimcilik davranışları ve bunun şirket performansına yansımaları üzerine etkisini inceledikleri çalışmada yarı-yapılandırılmış görüşme tekniğinden yararlanmıştır. Konuşma metninin transkripsiyonundan "finans, performans, başarı, karlılık" gibi kelimeleri tarayan yazarlar, finansal başarının önemli bir kriterinin şirket yönetimine aile entegrasyonu olduğunu savunmuştur. Hernández-Perlines, vd. (2017) girişimcilik oryantasyonunun ve özümseme (yeni bilgiyi tanımlama, özümseme ve kullanma) kapasitesinin aile şirketi performans1 üzerindeki etkisini araştırmaktadır. Yapısal eşitlik modellemesi yoluyla 218 İspanyol aile şirketini inceleyen çalışma, girişimcilik yönelimin firma başarısının ve değer yaratma kapasitesini etkileyen bir faktör olduğunu savunmaktadır. Yazarlar, aile şirketi performansını (satışlardaki artış, karlılık oranı, piyasa payındaki büyüme oranı) likert ölçeği yoluyla değerlendirmiş olup, özümseme kapasitesinin artması ile girişimcilik faaliyetlerinin şirket performansına yansımasının arttığını savunmaktadır.

Lee ve Marshall (2013) 1997-2000 yılları arasinda ABD'de 14000 adet şirkette uygulanan Ulusal Aile İşletmeleri Anketinin (National Family Business Surveys -NFBS) çalışma verisi regresyon analizi yoluyla analiz edilmiştir. 3 yıl ara ile şirketler tarafindan belirlenen işletme stratejilerin şirket performansına yansımalarını inceleyen çalışma, girişimcilik faaliyetlerin işletme performansı üzerinde istatistiksel olarak anlamlı bir etkisi olduğunu göstermektedir. Zamanla aile ve şirket hedeflerinin iç içe geçmiş olduğunu savunan Lee ve Marshall (2013), işletme büyüklügü ve finansal başarısını (karlılık oranı) üzerinde önemli bir etkisinin olmasının kaçınılmaz olduğunu ifade etmektedir. Laforet (2013) İngiltere'de $500 \mathrm{KOBİ} \mathrm{aile} \mathrm{şirketinin} \mathrm{çevre,} \mathrm{inovasyon} \mathrm{stratejisi,} \mathrm{kültürü,} \mathrm{şirket}$ yönetiminde aile katılımı, ve finansal performansına yansımalarını inceleyen bir çalışma yapmıştır. Posta yoluyla gönderilen anketten toplanan veri regresyon analizi ile analiz edilmiştir. Aile şirketlerinde finansal performansı büyüklük açısından inceleyen Laforet (2013), aile bireylerinin inovasyon sürecine dahil olması ile genç şirketlerin inovasyon davranışlarını olumlu etkilendiğini savunmaktadır. Spriggs vd. (2013) çalışmasında 1997- 2000 yılları arasında uygulanmış olan 199 sorulu Aile İşletmeleri Anketinden (Survey of Family Business) yararlanmış olup, faktör analiz (açıklayıcı ve doğrulayıcı faktör analizi) ve regresyon analizi ile aile şirketlerindeki mülkiyet yapısının sağladığı avantajları incelemektedir. Yazar, anket ile toplanan finansal performans (3-5 yıllık sektör içi büyüme oran1, kârlılık ve piyasa payı) verisi ile inovasyon göstergelerini karşılaştırarak, girişimcilik davranışlarının şirket karlılığ üzerine olumlu bir etkisi olduğunu tespit etmiştir. Altindag vd. (2011) İstanbul Ticaret Odası veri tabanından rastgele örnekleme yöntemini kullanılarak 500 şirket seçmiştir. Anket ve yüz yüze görüşme tekniği 280 yönetici/işletme sahibinden veri toplanılmıştır. Stratejik yönelim seviyelerinin firma performansı üzerindeki etkilerini Türkiye'de 
inceleyen çalışma aile şirketi olup/olmamanın ilişkiye etkisi incelenmiştir. Bulgular veri güvenilirliği ve faktör analizleri ile test edildikten sonra, boyutlar arasındaki ilişkileri değerlendirmek için regresyon analizleri kullanılmıştır. Sonuç olarak, stratejik yönelimlerin aile firmalarının niteliksel ve niceliksel performansı üzerindeki olumlu etkilerinin olduğu tespit edilmiştir. Zehir vd. (2011) benzer şekilde İstanbul Ticaret Odası veri tabanından 159 aile şirketine stratejik yönelim seviyelerinin firma performansına etkilerini inceleyen bir anket çalışması yapılmıştır. Aile şirketlerini pazar payı, karlılık oranı, satıştaki büyümesi, yatırım getirisi ve genel performanstaki iyileşmeler açısından inceleyen yazar, girişimcilik yöneliminin şirket karlılığı ve büyüme oranını olumlu bir şekilde etkilediğini savunmaktadır.

Martínez vd. (2016) Aile Şirketi Bölgesel Birliğine (Family Business Regional Association) kayıttılı 480 aile şirketine anket yollamıştır. \%19 oranında 93 adet katılımcı ile geri dönüş sağlayan çalışmada girişimcilik yöneliminin geliştirilmesi ile bilgi aktarımının ve performans üzerine etkisi araştırılmaktadır. Finansal performansı karlık, satışlarda artış, nakit akışı ve net değer artışı açısından inceleyen çalışma, yüksek girişimcilik yönelimi seviyeleri gösteren aile şirketlerinin daha iyi bir performans sergiledikleri görülmüştür. Memili vd. (2010) İsviçre'de 163 aile şirketi yöneticisine uyguladığı ankette, örgütsel kimlik teorisinden yola çıkarak, aile mülkiyeti ve aile beklentilerinin şirketi imajını, risk-alımı davranışını ve şirket performansını (satışlarda ve pazar payı büyümesi) nasıl etkilediğini araştırmaktadır. Yedili likert ölçeği yoluyla toplanan veri, açıklayıcı faktör analizi ile incelenmiştir. Yapılan çalışma sonucunda girişimcilik faaliyetlerinin aile şirket performansını yönlendirdiği, dolayısı ile nesiller arası başarı elde etmek isteyen yöneticilerin bu aktiviteleri desteklemesi gerektiği savunulmaktadır. Son olarak, Lee ve Chu (2017) Taiwan'da 223 şirkete Miller (1983); Covin ve Slevin (1991) tarafından geliştirilmiş ölçeği anket yoluyla uygulayarak, girişimci yöneliminin finansal performans (varlık getirisi ve Tobin q) üzerine etkisini incelemektedir. Veri doğrulayıcı faktör analizi ve yapısal eşitlik modelleme ile analiz edilmiştir. Sonuç olarak, girişimcilik yöneliminin finansal başarı ve büyümeyi yönlendiren bir güç olduğu ve iyi tasarlanmış bir organizasyon yapısının süreci hızlandırdığı savunulmaktadır. Yukarıda sunulan literatür doğrultusunda çalışmada değerlendirilecek hipotez aşağıda sunulmuştur:

H1: Şirketlerin girişimcilik yönelimi derecesi ile finansal performansı arasındaki ilişki üzerinde şirketlerin aile şirketi olmasinın düzenleyici etkisi vardır.

$\mathrm{Bu}$ alanda yapılan çalışmalar değerlendirildiğinde iki yargıya ulaşmak mümkündür: (1) girişimcilik yöneliminin, şirket finansal performansına yansımaları (olumlu veya olumsuz) olduğu ve (2) girişimcilik yönelimi kavramının ölçümünün sübjektif tekniklere (Wales, vd. 2019) ve veriye dayandığı (Lyon vd., 2000). Dolayısı ile, literatürde "aile şirketlerinde girişimci yönelimini ampirik olarak inceleyecek" çalışmalara (Casillas ve Moreno, 2010; Uhlaner vd. 2012) yönelik çağrıya cevap verecek olan bu makalede, objektif veriler yoluyla ölçülebilir ve uluslararası/sektörler arası karşılaştırılabilir bir girişimcilik yönelim 
modeli geliştirilecektir. Çalışmanın bir sonraki bölümünde geliştirilen modelin metodolojisi detaylı bir şekilde ele alınacaktır.

\section{METODOLOJI}

$\mathrm{Bu}$ çalışmanın amacı literatürde vurgulanan girişimcilik davranışları-finansal şirket performansı arasındaki ilişkide aile şirketlerinin düzenleyici rolünü incelemektedir. İlişkiyi test edebilmek adına karşılaştırılabilir ve objektif veriler yolu ile ölçülebilir bir girişimcilik yönelim modeli geliştirilecektir. İki değişken arasındaki ilişkinin üçüncü bir değişkenin değerine bağlı olup/olmadığını, o değişkenden dolayı ilişkinin etkilenip/etkilenmediğini belirlemek için moderatör analizi kullanılmaktadır. Bu çalışmada ortaklık yapısı, girişimcilik yönelimi - firma performansı arasındaki ilişkiyi açıklayan moderatör değişken (dikotojen moderatör değişken) olarak ele alınacaktır. Girişimcilik yönelimi (sürekli bağımlı değişken) ve şirket performans göstergeleri (sürekli bağımsız değişken) arasındaki ilişki Moderatörlü Çoklu Regresyon Analizi yoluyla SPSS 23 programında test edilecektir. Şirketlerin girişimcilik yöneliminin ampirik olarak test edilebilmesi amacıyla ilk önce bir endeks oluşturulacaktır. Miller (1983) tarafından geliştirilen ve bu çalışma altında baz alınan "inovasyon, risk-alma ve proaktiflik" boyutlu girişimcilik yönelimi kavramı literatür destekli bir şekilde ampirik olarak hesaplanacaktır. Her şirket için oluşturulan bileşen daha sonra Temel Bileşenler Analizi yardımı ile bir endeks altında toplanacaktır. Grace-Martin (2019) ve Atchley vd. (2015) 'a göre Temel Bileşenler Analizi (TBA), çok değişkenli bir veri seti içerisindeki bilgiyi daha az değişkenle ve minimum bilgi kaybıyla açıklamanın bir matematiksel tekniğidir. Başka bir şekilde ifade etmek gerekirse, TBA çok sayıda birbiri ile ilişkili değişkenler içeren veri setinin boyutunu, veri seti içerisindeki veriyi koruyarak daha küçük boyuta indirgenmesini sağlayan bir dönüşüm tekniğidir. Dönüşüm sonrasında elde edilen değişkenler, temel bileşenleri veya "endeks" olarak adlandırılır. 2018 yılında BİST imalat sektöründe faaliyet gösteren 178 şirket analizin ilk aşamasında baz alınmıştır. Analiz birimini şirketler oluşturduğu için Adana Çimento ve Kardemir Karabük şirketlerinin tek hissesi (A) sadece çalışmaya dahil edilmiştir. Aşağıda her bileşen için baz alınan ampirik metodoloji sunulmuştur.

Inovasyon: İnovasyonun hesaplanması için Siddiquee vd. (2015) tarafindan öner sürülen ölçüt "Araştırma ve geliştirme giderleri" baz alınmıştır. Şirketlerin 2014-2018 finansal raporlarından toplanan değer, kategorik olarak harcama yapıp "1", yapmamasına " 0 " göre kodlanmıştır. Örneklemin 5 yıllık giderlerinin toplanması sonucunda 78 adet şirketin ARGE harcaması olmadığ tespit edilmiş, dolayısı ile analizden çıkartılmıştır. Sonuç olarak, analizin ilk aşamasında çalışmaya dahil edilen 178 adet şirket 100 'e indirgenmiştir. ARGE yatırımları genellikle uzun bir dönemi kapsadığı ve dönemsel olarak değiştiği için, tek bir yıllın analiz altında baz alınması hatalı sonuçlar doğurabilir. Çalışmaya tek bir yılın dahil edilmesi elde edilen sonuçların güvenirliği düşük veya şirketlerin inovatif davranışları hakkında sınırlı bilgi sunduğu için, 5 yılın ortalaması alınarak ARGE değeri hesaplanmıştır. 
Risk-alma: Her şirketin risk-alım eğilimi, son 5 y1llık varlık getiri volatilitesi (John vd. 2008; Boubakri vd. 2013), alt-sektör ortalamas1 (Örnek olarak, imalat sektöründe Metal Eşya, Metal Ana, Gıda..vb.) dikkate alınarak hesaplanmıştır. Risk alım eğilimini hesaplayabilmek için her şirketin faaliyet gösterdiği alt sektör Kamu Aydınlatma Platformundan kodlanmıştır. Örneklemin alt sektör dağılımı Şekil 1 altında sunulmuştur.

Şekil 1: Örneklem Dağılımı

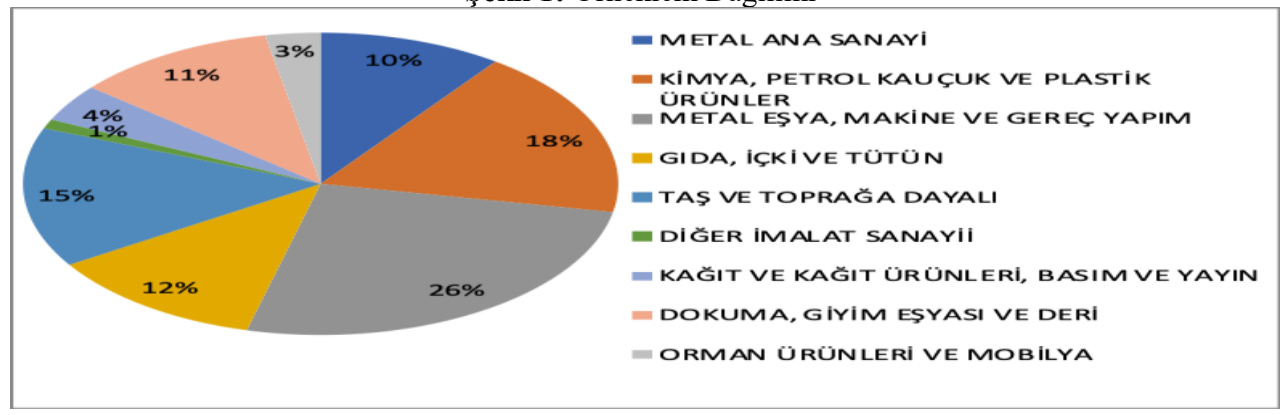

Şirketlerin alt sektörü kodlandıktan sonra risk-alımı eğilimine hesaplayabilmek için her sektörün ortalama varlık getiri oranının (Varlık Getirisi Oranı: Net Kar $\div$ Ortalama Toplam Varlıklar) belirlenmesi gerekmektedir. Her sektör için (9 adet) 5 yıllık (2014-2018) varlık getiri oranı tek tek hesaplanmış ve ortalaması alınmıştır. Baz alınan formülasyon aşağıda sunulmuştur (John vd. 2008; Boubakri vd. 2013).

$$
\begin{gathered}
R_{S S K_{i, t}}=\sqrt{\frac{1}{T-1} \sum_{t=1}^{T}\left(R O A_{i, t}^{a d j}-\frac{1}{T} \sum_{t=1}^{T} R O A_{i, t}^{a d j}\right)^{2}} \\
R O A_{i, t}^{a d j}=R O A_{i, t}-\frac{1}{N_{j, t}} \sum_{i \in \Theta j} R O A_{i, t}
\end{gathered}
$$

RISK $_{\mathrm{i}, \mathrm{j}} \mathrm{i}$ firmasının t yılında "risk-taking" olarak ifade edilen risk

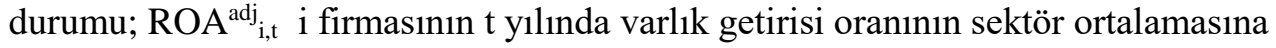
göre düzeltilmiş değeri; $\mathrm{N}_{\mathrm{J}, \mathrm{t}} \mathrm{j}$ sektöründe $\mathrm{t}$ yılında faaliyet gösteren şirket sayısını ifade etmektedir. Örneklem içerisinde ağırlıklı olarak kodlanan sektör \%26 ile Metal Eşya Makine ve Gereç Yapımı sektörüdür. İkinci ve üçüncü ağıllıklı sektörler ise \%18 ile Kimya Petrol Kauçuk ve Plastik ürünler sektörü ve \%15 ile Taş ve Toprağa Dayalı Ürünler sektördür. Örneklem içerisinde en az yer kaplayan sektör ise \%1 ile Diğer İmalat Sanayi sektördür. Yapılan hesaplamalar sonucunda tespit edilen değerler Dokuma Giyim Eşyası ve Deri sektörü için örnek olarak sunulmuştur: 2015 Dokuma Giyim Eşyası ve Deri sektörünün varlık getirisi oranı (0.013), 2016 için (-0.011), 2017 için (0.019), 2018 için ise (0.004) değerleri tespit edilmiştir. Hesaplanan yıllık sektörel oranlar, dönüştürülmüş varlık getiri oranının hesaplanmasında kullanılacaktır. Her örneklem için 2013-2018 yılları arası net kar ve varlık bilgisi şirket finansal raporlarından toplanmış olup, 2014-2018 varlık getirisi oranı hesaplanmıştır. Bir sonraki aşamada şirketlerin 2014-2018 yılları 
arası varlık getiri oranlarından o yıla hitap eden sektör ortalaması değerinden çıkartılmıştır. Elde edilen değer bize düzenlenmiş varlık getiri oranını vermiştir. Son olarak, oranın standart sapması alınmıştır ve şirketlerin risk-alım oranı belirlenmiştir.

Proaktiflik: Girişimcilik yönelimi endeksinin hesaplanmasında kullanılan son bileșen proaktiflik'tir. Proaktiflik değerinin ampirik olarak hesaplanmasında Edelig ve Himine (2018)'nin çalışması baz alınmıştır. Edelig ve Himine (2018), girişimci şirketlerde proaktif (yeni yatırım yapılması, piyasaya yeni ürün sürülmesi...vb.) faaliyetlerin yatırımcılar tarafından algılanıp, hisse senedi fiyatlarına yansıtıldığını savunmaktadır. Dolayısı ile, şirket proaktifliğinin hesaplanılmasında kapanış hisse değerlerinin 5 yıllık ortalaması baz alınacaktır. Analizde kullanılacak 5 y1llik (2014-2018) veri "big-para" sitesinden (http://bigpara.hurriyet.com.tr/borsa/hisse-fiyatlari/) indirilmiştir. Girişimcilik yönelimi bileşenleri hesaplandıktan sonra Temel Bileşen Analizi ile bir endeks oluşturulacaktır. Örnekleme dahil her şirket için hesaplanan girişimcilik yönelimi değeri ortaklık yapısı ve finansal performans göstergeleri ile karşılaştırılacaktır.

Ortaklık yapısı: BİST imalat sektörü şirketlerinin ortaklı yapısının belirlenmesinde Croci vd. (2011); Masulis (2011) tarafından öne sürülen kriterler baz alınmıştır. Örneklem şirketlerin aile şirketi olup "1", olmaması "0" durumunu kategorik olarak kodlayabilmek için şirketlerin doğrudan sahiplik yapıları incelenmiştir. Şirket web-sitelerinden ve Kamu Aydınlatma Platformunda sunulan veriden yararlanarak şirketlerin doğrudan sahiplik payları yüzde beşten fazla olan ortakların payları (seviye 1) Excel altında toplanmıştır. Çalışmada işletmelerin oy hakkı yapıları, yani kontrol seviyesi, baz alınmıştır. İlgili şirket, en yüksek oy hakkı olan grup altında kodlanmıştır. Eğer aile üyelerinin paylarının toplamı diğer hissedarlardan daha yüksekse, şirket aile şirketi olarak kodlanmıştır. Ek olarak, eğer ilgili şirket aile üyeleri tarafından kontrol edilen başka bir firmanın iştiraki ise şirket aile şirketi olarak kodlanmıştır. Şirketlerin ortaklık yapıları halka kapalı bir iştirake ulaşıncaya kadar (seviye 2 ve 3) kodlanmıştır. Yukarıda bahsi geçen kriterler doğrultusunda örneklem şirketlerinin ortaklık yapısı ve ortaklık türü (Kişi, Aile, Holding, Şirket, Finansal Kuruluş, Diğer (Halka Açıklık \%) incelenmiştir. 100 şirket içerisinde 17 tanesinin direk aile sahipliğinin olduğu, iki ve üçüncü seviyede incelendiğinde ise 50 şirketin aile şirketi olduğu tespit edilmiştir. Çalışmaya dahil edilen 100 adet şirketin ortaklık yapısı incelendiğinde kuruluşların ortaklık paylarının yüzdelikleri Şekil 2-4 altında sunulmuştur.

Şekil 2: Örneklemin Ortaklık Yapıs1

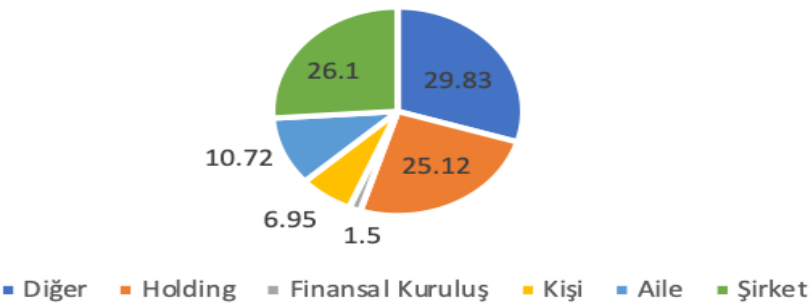


Şekil 3: Örneklemin Aile Şirketi Dağılımı (Seviye 1)

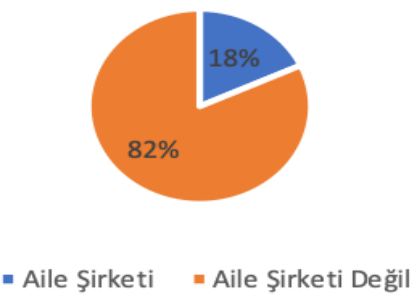

Şekil 4: Örneklemin Aile Şirketi Yapısı (Seviye 2)

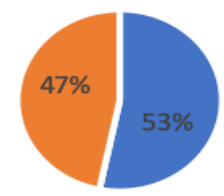

- Aile Şirketi = Aile Şirketi Değil

Finansal performans göstergeleri: Literatürden toplanan finansal performans göstergeleri aşağıda Tablo 1'de sunulan formüller doğrultusunda hesaplanmıştır. 2017-2018 denetlenmiş yıllık finansal rapor verisi Finnet programı yardımı ile indirilmiştir.

Tablo 1: Finansal Performans Göstergeleri

\begin{tabular}{|c|c|c|}
\hline Rasyo & Formülasyon & \begin{tabular}{|l} 
Analiz \\
Türü
\end{tabular} \\
\hline Nakit Oranı & $\begin{array}{l}\text { (Hazır Değerler + Menkul Kiymetler) / Kısa Vadeli Yaba } \\
\text { nc1 Kaynaklar }\end{array}$ & Likidite \\
\hline Asit - Test Oranı & $\begin{array}{l}\text { (Dönen Varlıklar - Stoklar) / Kısa Vadeli Yabancı Kaynak } \\
\text { lar }\end{array}$ & Likidite \\
\hline Cari Oran & Dönen Varlıklar / Kısa Vadeli Yabancı Kaynaklar & Likidite \\
\hline Stok Bağımlılık Oranı & $\begin{array}{l}{[\text { Kisa Vadeli Yabancı Kaynaklar - (Hazır Değerler + Men }} \\
\text { kul Kıymetler)] / Stoklar }\end{array}$ & Likidite \\
\hline Kaldıraç Oranı & $\begin{array}{l}\text { (Kisa Vadeli Yabanc1 Kaynaklar + Uzun Vadeli Yabanc1 } \\
\text { Kaynaklar) / Toplam Varlıklar }\end{array}$ & \begin{tabular}{|l} 
Finansal \\
Yap1
\end{tabular} \\
\hline Finansman Oranı & $\begin{array}{l}\text { Öz Kaynaklar / (Kısa Vadeli Yabancı Kaynaklar + Uzun } \\
\text { Vadeli Yabancı Kaynaklar) }\end{array}$ & \begin{tabular}{|l}
$\begin{array}{l}\text { Finansal } \\
\text { Yap1 }\end{array}$ \\
\end{tabular} \\
\hline Borç/Özsermaye Oranı & $\begin{array}{l}\text { (Kisa Vadeli Yabancı Kaynaklar + Uzun Vadeli Yabancı } \\
\text { Kaynaklar) / Öz Kaynaklar }\end{array}$ & \begin{tabular}{|l} 
Finansal \\
Yap1
\end{tabular} \\
\hline $\begin{array}{l}\text { Duran Varlıklar/Devamlı } \\
\text { Sermaye Oranı }\end{array}$ & $\begin{array}{l}\text { Duran Varlıklar / (Uzun Vadeli Yabancı Kaynaklar + Öz } \\
\text { Kaynaklar) }\end{array}$ & \begin{tabular}{|l} 
Finansal \\
Yap1
\end{tabular} \\
\hline Alacak Devir Hızı & Net Satışlar / Kısa Vadeli Ticari Alacaklar & Faaliyet \\
\hline Stok Devir Hızı & Satışların Maliyeti / Ortalama Stok & Faaliyet \\
\hline Borç Devir Hızı & $\begin{array}{l}\text { (Satışların Maliyeti + Dönem Sonu Stok - Dönem Başı St } \\
\text { ok) / Ortalama Ticari Borç }\end{array}$ & Faaliyet \\
\hline
\end{tabular}


Melissa Cagle \& Ahmet Özen / Girişimcilik Yönelimi ve Finansal Performans İlişkisinin Araştırılmasında Aile Şirketlerinin Moderatör Rolü

\begin{tabular}{|l|l|l|}
\hline Ekonomik Rantabilite & $\begin{array}{l}\text { Vergi ve Faiz Önceki Kâr / (Kısa Vadeli Yabancı Kaynak } \\
\text { lar + Uzun Vadeli Yabancı Kaynaklar + Öz Kaynaklar) }\end{array}$ & Karlıık \\
\hline İş Hacmi Rantabilitesi & Faaliyet Kârı / Net Satışlar & Karlılık \\
\hline Özsermaye Kârlılık Oranı & Net Kar / Ortalama Özsermaye & Karlılık \\
\hline
\end{tabular}

Analize dahil edilecek değerler hesaplandıktan sonra Moderatörlü Çoklu Regresyon Analizi uygulanacaktır. Analizin ilk aşamasında moderatör analizinin varsayımları test edilecek olup, ikinci aşamasında moderatör etkisinin olup/olmadığ 1 belirlenecektir. Çalışmada test edilen varsayımlar; doğrusallık, çok bağlantı (multicollinearity), aykırı değerler, kaldıraç noktaları ve etkili vakalar, değişen varyans (homoscedasticity) ve normallik. Çalışmanın bir sonraki bölümünde analizin bulguları sunulmuştur.

\section{BULGULAR}

Girişimcilik yönelimi bileşenleri hesaplandıktan sonra Temel Bileşen Analizi ile bir endeks oluşturulmuştur. Analize dahil edilen bileşenlerin tanımlayıcı istatistikleri Tablo 2 altında özetlenmiştir.

Tablo 2: Tanımlayıcı İstatistikler

\begin{tabular}{|l|l|l|l|l|l|}
\hline & $\mathrm{N}$ & Minimum & Maximum & Ortalama & Std. Sapma \\
\hline Risk & 100 & .00 & .23 & .0509 & .03654 \\
\hline Stok (5 y1llk) & 100 & .25 & 231.08 & 10.81 & 26.47 \\
\hline ARGE (5 y1llik) & 100 & 1094 & 301373879 & 10076977 & 37162286 \\
\hline
\end{tabular}

Temel Bileşen Analizi SPSS 23 programı ile hesaplanmıştır. TBA'nın bir varsayımı değerlerin nominal dağılması olduğu için 3 değişken SPSS altında Templeton (2011) tarafindan önerilen iki aşamalı dönüşüm süreci ile normalize edilmiştir. Normalizasyon sonucunda elde edilen değerler TBA'ya dahil edilmiştir. Aşağıda sunulan Tablo 3'den de görüleceği üzere endeksin Barlett değeri anlamlı çıkmıştır. Bu sonuç üç değişkenin bir endeks altında toplanmaya uygun olduğunu göstermektedir. KMO analizi ise $\% 54$ çıkmış olup, endeksin gücü hakkında bilgi vermektedir. KMO \%60'a yakın olduğu ve değerler arası korelasyon ilişki tespit edilmediği için (Tablo 4) değişkenler endeks oluşturmak için uygun olduğu savunulmaktadır. Temel bileşenler analizi sonunda birinci bileşenin toplam varyasyonun \%47.72'sini açıkladığını tespit etmiş.

Tablo 3: KMO ve Bartlett Testi

\begin{tabular}{|l|l|l|}
\hline Kaiser-Meyer-Olkin Measure of Sampling Adequacy & .541 \\
\hline \multirow{3}{*}{ Bartlett's Test of Sphericity } & Approx. Chi-Square & 15.036 \\
\cline { 2 - 3 } & df & 3 \\
\cline { 2 - 3 } & Sig. & .002 \\
\hline
\end{tabular}

Tablo 4: Değişkenler Arası Korelasyon

\begin{tabular}{|l|l|l|l|l|}
\hline \multicolumn{2}{|c|}{} & NormRisk & NormStok & NormARGE \\
\hline \multirow{3}{*}{ Correlation } & NormRisk & 1.000 & -.104 & -.169 \\
\cline { 2 - 5 } & NormStok & -.104 & 1.000 & .345 \\
\cline { 2 - 5 } & NormARGE & -.169 & .345 & 1.000 \\
\hline \multirow{3}{*}{ Sig. (1-tailed) } & NormRisk & & .154 & .048 \\
\cline { 2 - 5 } & NormStok & .154 & & .000 \\
\cline { 2 - 5 } & NormARGE & .048 & .000 & \\
\hline
\end{tabular}


TBA sonucunda hesaplanan Girişimcilik Yönelimi Endeksinin sektörel dağılımı aşağıda sunulmuştur. Pozitif girişimcilik yönelimine sahip 43 şirket bulunmaktadır. Genel sektörel ortalamaya bakıldığında Kimya ve Metal Eşya sektörlerinin girişimcilik yönelimi değerlerinin yüksek olduğu görülmektedir. Ancak örneklem şirketlerin girişimcilik yönelimi değeri tek tek incelendiğinde ilk 10 şirketin (Tablo 5) \%70'inin Metal Eşya, \%20'sin Gıda ve \%10'unu Kimya sektörünün oluşturduğu görülmektedir.

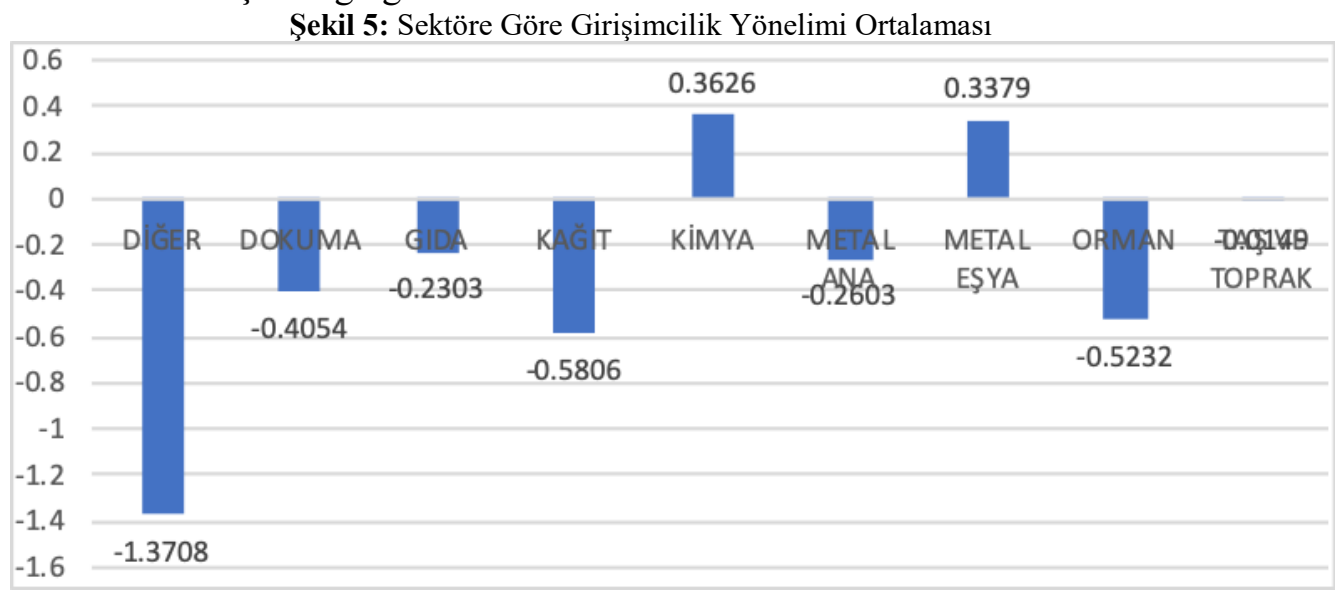

Tablo 5: En Yüksek Girişimcilik Yönelimine Sahip 10 Şirket

\begin{tabular}{|c|c|c|c|c|c|c|}
\hline$\#$ & Şirket & Alt Sektör & Inovasyon & Risk-Alımı & Proaktiflik & Girişimcilik Yönelimi \\
\hline 1 & Pınar Süt & Gida & 10637650 & 0.02 & 12.09 & 1.36 \\
\hline 2 & Vestel Beyaz Eşya & Metal Eşya & 33317800 & 0.03 & 9.40 & 1.48 \\
\hline 3 & Ülker Bisküvi & Gida & 11548133 & 0.02 & 16.83 & 1.53 \\
\hline 4 & Türk Traktör & Metal Eşya & 14168199 & 0.04 & 57.19 & 1.72 \\
\hline 5 & Arçelik & Metal Eşya & 150773000 & 0.02 & 16.52 & 2.01 \\
\hline 6 & Alarko Carrıer & Metal Eşya & 7551657 & 0.01 & 37.12 & 2.05 \\
\hline 7 & Vestel Elektronik & Metal Eşya & 162630600 & 0.01 & 6.18 & 2.09 \\
\hline 8 & Tofaş & Metal Eşya & 33978000 & 0.01 & 18.51 & 2.35 \\
\hline 9 & Tüpraş & Kimya & 20312000 & 0.01 & 67.52 & 2.52 \\
\hline 10 & Otokar & Metal Eşya & 38856088 & 0.01 & 96.87 & 2.97 \\
\hline
\end{tabular}

En yüksek girişimcilik yönelim değerine sahibi 10 şirket tablo altında inovasyon, risk-alma ve proaktiflik değerleri ile beraber sunulmuştur. Değerler incelendiğinde Araştırma ve Geliştirme giderlerinin ve hisse değerlerinin bu şirketler için yüksek olduğu, ancak risk-alım eğiliminde olmadıkları, riskten kaçındıkları görülmektedir. Aksine risk-alımı değeri yüksek çıkan şirketlerin girişimcilik yöneliminin daha düşük olduğu sıralamada görülmüştür. Örnek olarak, en yüksek risk-alımına sahip şirketler sıralandığında girişimcilik değerlerinin -1.4 ile 0.30 arasında değiştiği ve ortalama değerin -0.67 olduğu görülmüştür. Bu veriler sonucunda girişimcilik yönelimi yüksek olan şirketlerin risk almaktan kaçındığ 1 veya daha temkinli kararlar aldığı söylenebilir. Şekil 6-8 altında sektörel olarak şirketlerin inovasyon, proaktiflik ve risk-alım değerleri sunulmuştur. 
Melissa Cagle \& Ahmet Özen / Girişimcilik Yönelimi ve Finansal Performans İlişkisinin Araştırılmasında Aile Şirketlerinin Moderatör Rolü

Şekil 6: Sektöre Göre İnovasyon Ortalaması

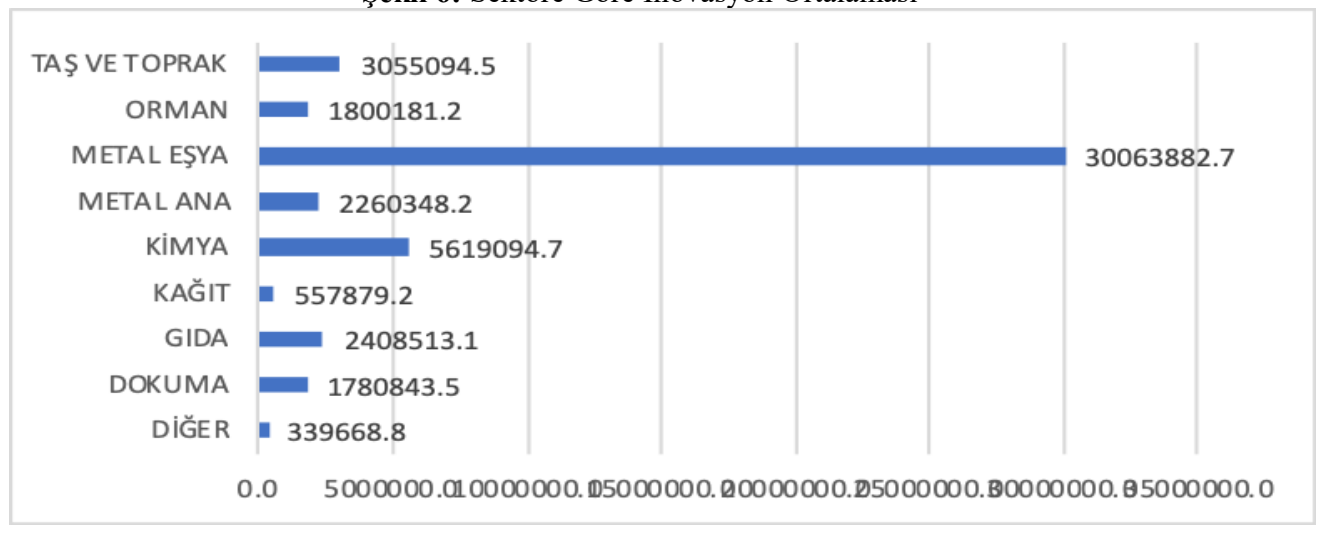

Şekil 7: Sektöre Göre Proaktiflik Ortalaması

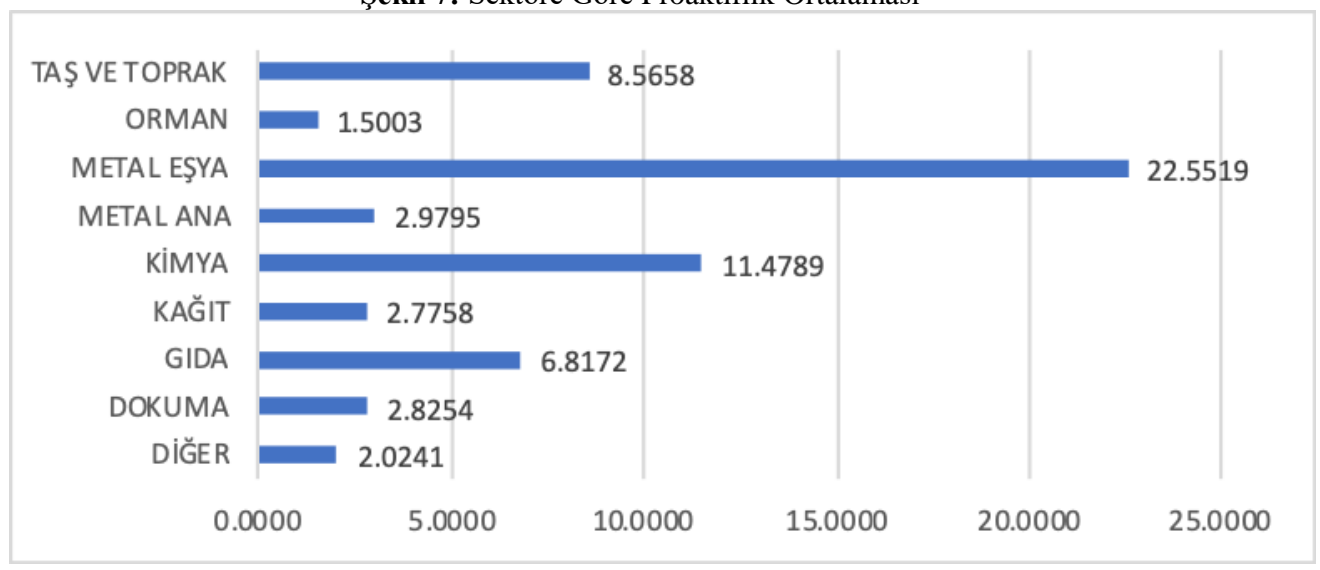

Şekil 8: Sektöre Göre Risk-Alımı Ortalaması

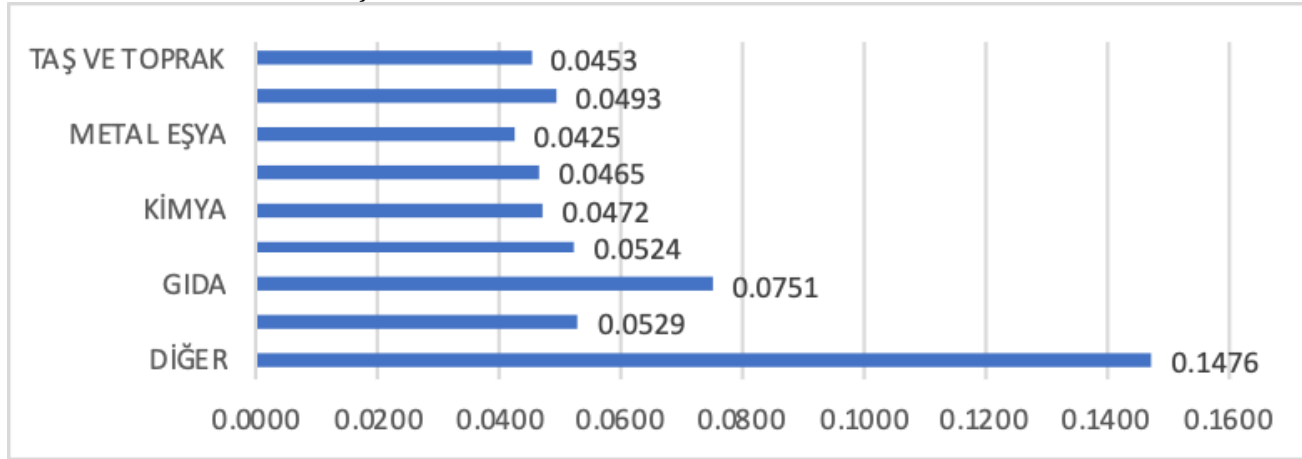

Girişimcilik yönetim bilişimleri incelendiğinde en inovatif ve proaktif sektörün Metal Eşya olduğu, ve risk-alım eğilimi yüksek olan sektörün ise Diğer İmalat sektörü olduğu tespit edilmiştir. Benzer şekilde ikinci ve üçüncü inovatif ve proaktif sektörün sırası ile Kimya ve Taş, Toprak sektörü olduğu görülmüştür. Risk-alım eğilimi en yüksek olan ikinci sektör ise Gıda sektörüdür. 
TBA analizi sonucunda belirlenen endeks Moderatörlü Çoklu Regresyon Analizi yoluyla SPSS 23 programında test edilmiştir. Ancak, moderatör analizinin uygulanabilmesi amacıyla ilk önce belirli varsayımları sağlaması gerekmektedir. İlk varsayım doğrultusunda kullanılacak bağımlı ve bağımsız değişkenlerin sürekli (continuous) veya oran değişken olması gerekmektedir. Girişimcilik yönelimi ve şirket performans değerlerimiz bu varsayımı sağlamaktadır. Çalışmanın ikinci varsayımı moderatör değişkenin ikili düzeyde (dichotomous) ölçülen kategorik olarak kullanmış bir değişkenden oluşmasıdır. Moderatör değişkenin ikili düzeyde kullanabilmesi amacı ile şirketin ortaklık yapısı toplanarak ailelerin şirket içerisinde yüzdelik sahipleri dikkate alınarak yeni bir değişken oluşturulmuştur. $\mathrm{Bu}$ değişken, şirketin ağırlıklı olarak aileler tarafından yönetilip/yönetilmediğini ifade etmektedir. Seviye 1 ve 2'de ortaklık yapısı ikili değişken (1 ve 0 ) olarak kodlanıp, moderatör olarak kullanılabilecek bir formata getirilmiştir. Dolayısı ile modertör analizinin üçüncü varsayımı sağlamıştır. Moderatör analizinin dördüncü varsayımı ise gözlemlerin birbirinden bağımsız olmasıdır. Uygulanan korelasyon analizi sonucunda finansal performans göstergeleri ve girişimcilik yönelimi endeks değeri arasından güçlü, anlamlı bir ilişki tespit edilmemiştir. Sadece Özsermaye Karlılık Oranı $(r=0.300, p=0.03)$ ve Stok Devir Hızı $(r=0.227, p=0.02)$ ile girişimcilik yönelimi arasında bir ilişki tespit edilmiştir. Ancak güçsüz pozitif korelasyon olduğu için verinin moderatör ilişkiyi hesaplamaya uygun olduğu savunulmaktadır. Analizin bu aşamasından sonra moderatör ilişkinin varlığ test edilecektir. Çalışma altında iki moderatör değişken hesaplanmıştır; ortaklık yapısı seviye 1 ve ortaklık yapısı seviye 2. Moderatör analizin tüm varsayımları her iki değişken için ayrı ayrı test edilmiştir. Bağımsız değişkenler ile bağımlı değişken arasında doğrusal ilişkili olmadığı için, verilerin Log10'u alınmıştır. Bağımsız ve moderatör değişkenler arasında çok bağlantı (multicollinearity) bir ilişkiye rastlanmamıştır. 2018 finansal raporları yayınlanmamış olduğu için iki şirket bu aşamada analizden çıkartılmıştır. Verilerde aykırı 4 değer "studentized_deleted" değerinin üzerinde olduğu için ilgili bağımsız değişkenlerde örneklemden çıkartılmıştır. Son örneklem sayısı, moderatör analizi aşamasında 94 adete düşmüştür. Çalışmada "kaldıraç noktaları" ve "etkili vakalar" gözlemlenmemiştir. Etkili vakalar regresyon çizgisini değiştiren gözlemlerdir. Kaldıraç noktaları ise bağımsız değişkenler içerisinde olağandışı bir kombinasyona sahip değerlerden oluşmaktadır. Heteroskedasticity SPSS programı altında macro yardımı olmadan test edilemeyeceği için Daryanto (2018) tarafindan geliştirilen macro kullanılmıstır.

Tablo 6: Breusch-Pagan and Koenker (Seviye 1)

\begin{tabular}{|l|l|l|}
\hline & LM & Sig \\
\hline BP & 11.069 & .805 \\
\hline Koenker & 12.929 & .678 \\
\hline
\end{tabular}

Tablo 7: Breusch-Pagan and Koenker (Seviye 2)

\begin{tabular}{|l|l|l|}
\hline & LM & Sig \\
\hline BP & 23.914 & .091 \\
\hline Koenker & 25.656 & .059 \\
\hline
\end{tabular}


Analiz sonucunda Homoscedastiklik varsayımının her iki seviye için karşılandı̆̆ $(\mathrm{p}>0.05)$ görülmüştür.

Tablo 8: Normal Dağ 11 ım (Seviye 1)

\begin{tabular}{|c|c|c|c|c|c|c|}
\hline & \multicolumn{3}{|c|}{ Kolmogorov-Smirnov } & \multicolumn{3}{|c|}{ Shapiro-Wilk } \\
\hline & Statistic & $\mathrm{df}$ & Sig. & Statistic & df & Sig. \\
\hline Studentized Residual & .078 & 93 & $.200^{*}$ & .986 & 93 & .422 \\
\hline
\end{tabular}

Tablo 9: Normal Dağılım (Seviye 2)

\begin{tabular}{|l|l|l|l|l|l|l|}
\hline & \multicolumn{3}{|l|}{ Kolmogorov-Smirnov' } & \multicolumn{3}{l|}{ Shapiro-Wilk } \\
\cline { 2 - 7 } & Statistic & df & Sig. & Statistic & df & Sig. \\
\hline Studentized Residual & .057 & 93 & $.200^{*}$ & .986 & 93 & .440 \\
\hline
\end{tabular}

Benzer şekilde "Studentized residuals" değerleri Shapiro-Wilk's test ( $\mathrm{p}>$ .05) olarak tespit edilmiş ve her iki seviyede bağımsız değişkenler normal olarak dağılmıştır. Moderatör analiz varsayımlarını karşılayan Seviye 1 ve Seviye 2 ortaklık yapısı finansal performans-girişimcilik yönelimi ilişkisinde test edilmiştir. Moderatörlü Çoklu Regresyon Analizi her bir bağımsız değişken ve seviye (1 ve 2) tek tek uygulanmıştır. Literatürde savunulan hipotezin aksine, aile şirketlerinin girişimcilik yönelimi ve şirket performansı ilişkisini etkilemediği görülmektedir. Sadece seviye 2'de Alacak Devir Hızı ile girişimcilik yönelimi - şirket performansı arasında düzenleyici etki tespit edilmiştir. Ancak Alacak Devir Hızı ve seviye 2 arasında uygulanan moderatörlü regresyon sonucu $\mathrm{R}^{2}$ 'nin datanın sadece 0.06 'sinı anlattığ 1 ve \%94'ünün model tarafından açıklanamadığ1 tespit edilmiştir. Dolayısı ile, arada güçlü bir ilişki bulunmamaktadır. Sonuç olarak, literatürde savunulanın (Casillas ve Moreno, 2010; Zellweger ve Sieger, 2012) aksine aile şirketlerinde finansal performans ile inovatif, proaktif veya risk-alımı faaliyetlerin bir ilişkisi olmadığı, aile şirketlerinin bu ilişkiyi etkileyen düzenleyici varlığının olmadığ söylenebilir. Çalışma altında desteklenen "Şirketlerin girişimcilik yönelimi derecesi ile finansal performansı arasındaki ilişki üzerinde şirketlerin aile şirketi olmasının düzenleyici etkisi vardır" hipotezi desteklenememiştir.

Moderatörlü regresyona ek olarak aile şirketi olan/olmayan şirketlerin girişimcilik yönelimi bileşenleri (risk-alma, inovasyon ve proaktiflik) arasındaki ilişki incelenmiştir. Uygulanan Nokta Çift Serili (point-biserial) korelasyon analiz sonucunda seviye 1 'de aile mülkiyeti ile risk alma arasında istatistiksel olarak anlamlı bir ilişki $(\mathrm{r}(94)=0.243, \mathrm{p}=0.018)$ tespit edilmiştir. Dolayisi ile literatürde Naldi vd. (2007); Zellweger ve Sieger (2012); Craig vd. (2014) tarafindan savunulanın aksine, aile şirketlerinin diğer şirketlere nazaran daha çok risk aldığı tespit savunulabilir.

\section{SONUÇ}

Literatürde farklı şekillerde tanımlanan aile şirketlerinin ülke ekonomileri açısından yadsınamayacak düzeyde itici ekonomik ve sosyal bir gücü bulunmaktadır. Dünyanın serbest ekonomisindeki işletmelerin \%80'inden fazlasının aile şirketi olması ile beraber birçok ekonominin bel kemiği oluşturmaktadır. Türkiye'de \%95'i aile şirketi hüviyetinde olan ekonomimizde de benzer bir durum hakimdir. Girişimcilik özellikleri ve uluslararası başarıları 
yönünden dikkat çeken aile şirketlerinin inovasyon, proaktiflik ve risk-alma faaliyetlerinin finansal performansını olumlu bir şekilde etkilediği ve örgütsel başarı açısından hayati öneme sahip olduğu savunulmaktadır. Dolayısı ile, özellikle dünya ve Türkiye ekonomik gelişiminde de önemli bir rol oynayan bu şirketlerin girişimcilik davranışlarına artan ilgi bu çalışmayı yapmak için motivasyon yaratılmıştır. Karşılaştırılabilir ve daha objektif veriler yolu ile ölçülebilir bir girişimcilik yönelim modeli geliştirmeyi amaçlayan bu çalışmada Temel Bileşenler Analizi yardımı ile bir "Girişimcilik Yönelimi Endeksi" oluşturulmuştur. Ampirik olarak ölçüldüğünde anlamlı sonuçlar doğuran bu endeks, Moderatörlü Çoklu Regresyon Analizi uygulanarak aile şirketlerinde finansal performans - girişimcilik yönelimi ilişkisi test edilmiştir.

Uygulanan analiz sonucunda 2018 yılında BİST İmalat Sanayiinde kote şirketlerin "inovasyon, proaktiflik ve risk-alma" girişimcilik bileşenleri incelenmiştir. Çalışma neticesinde aile şirketlerinin mevcut ilişkide düzenleyici rolünün olmadığı, ancak risk alma eğiliminin daha yüksek olduğu görülmüştür.

Aile şirketi yapısı yoğunlukta olan BİST İmalat Sanayii şirketlerinde pozitif değerli girişimcilik yönelimine sahip olduğu (örneklemin \%43'ü) tespit edilmiştir. Buna ek olarak, en yüksek girişimcilik yönelimi değerlerinin Kimya ve Metal Eşya sektörlerinde olduğu görülmektedir. Dolayısı ile Kimya ve Metal Eşya sektörlerinin diğer sektörlere nazaran daha inovatif, proaktif olduğu ve risk-aldığ 1 söylenebilir. Girişimcilik özelliği en düşük olan şirketlerin Diğer İmalat Sektöründe faaliyet gösterdiği görülmüştür. Şirketlerin ortaklık yapısına bakmaksızın en girişimci şirketlerin araştırma ve geliştirme giderlerinin ve hisse değerlerinin bu şirketler için yüksek olduğu, ancak risk-alım eğiliminde olmadıkları tespit edilmiştir.

$\mathrm{Bu}$ veriler sonucunda girişimcilik yönelimi yüksek olan şirketlerin risk almaktan kaçındığı veya daha temkinli kararlar aldığı söylenebilir. Çalışmanın bir limitasyonu farklı yaşam döngüsünde olan aile şirketleri, farklı girişimci tutum ve hedeflere sahip olma ihtimalidir. Dolayısı ile bu çalışmayı geliştirmek adına örneklem şirketlerin yaşam döngüsü incelenerek girişimcilik yönelimi ve mevcut ilişkinin finansal performans üzerine etkisi araştırılabilir. Çalışmaya finansal olmayan değişkenler (örnek olarak, kurumsal sosyal sorumluluk göstergeleri) eklenerek incelenen performans kriterleri ayrıca genişletilebilir.

\section{KAYNAKÇA}

Akdoğan, A. (2000). Aile işletmelerinin Özellikleri ve Aile işletmelerinde Kurumsallaşma ihtiyaci. Erciyes Üniversitesi İktisadi ve İdari Bilimler Fakültesi Dergisi, (16), 31-47

Altindag, E., Zehir, C., ve Acar, A. Z. (2011). Strategic Orientations and their Effects on Firm Performance in Turkish Family Owned Firms. Eurasian Business Review, 1(1), 18-36.

Anderson, R. C., ve Reeb, D. M. (2003). Founding-family Ownership and Firm Performance: Evidence from the SveP 500. The Journal of Finance, 58(3), 1301-1328.

Arzubiaga, U., Iturralde, T., Maseda, A., ve Kotlar, J. (2018). Entrepreneurial Orientation and Firm Performance in Family SMEs: the Moderating Effects of Family, Women, and Strategic Involvement in the Board of Directors. International Entrepreneurship and Management Journal, 14(1), 217-244. 
Atchley, F. S., Rossman, J. M., ve Mishra, M. K. (2015). U.S. Patent No. 8,978,661.Washington, DC: U.S. Patent and Trademark Office.

Ateş, Ö. (2005). Aile şirketleri: Değişim ve Süreklilik. Ankara Sanayi Odas1.

Bettinelli, C., Sciascia, S., Randerson, K., ve Fayolle, A. (2017). Researching Entrepreneurship in Family Firms. Journal of Small Business Management, 55(4), 506-529.

Bloomberg (2018). Türkiye'nin En İyi Yönetilen Şirketleri Belirlendi. https://www.bloomberght.com/haberler/haber/2176102-turkiyenin-en-iyi-yonetilen-sirke tleri-belirlendi (21.05.2019)

Boubakri, N., Cosset, J. C., ve Saffar, W. (2013). The Role of State and Foreign Owners in Corporate Risk-taking: Evidence from Privatization. Journal of Financial Economics, 1083, 641-658.

Casillas, J. C., ve Moreno, A. M. (2010). The Relationship Between Entrepreneurial Orientation and Growth: The Moderating Role of Family Involvement. Entrepreneurship \& Regional Development, 22(3-4), 265-291.

Church, R. A. (1969). Kenricks in Hardware: A Family Business, 791-1966. Newton Abbott: David ve Charles.

Covin, J. G., ve Slevin, D. P. (1989). Strategic Management of Small Firms in Hostile and Benign Environments. Strategic management journal, 10(1), 75-87.

Covin, J. G., ve Slevin, D. P. (1991). A Conceptual Model of Entrepreneurship as Firm Behavior. Entrepreneurship theory and practice, 16(1), 7-26.

Covin, J.G., ve Slevin, D. P . (1986). The Development and Testing of an Organization level Entrepreneurship Scale. (R. Ronstadt, J. A . Hornaday, R. Peterson, ve K. H. Vesper (Eds.), Frontiers of entrepreneunhip research, 1986 (pp. 628-639). Wellesley) MA: Babson College.

Craig, J. B., Pohjola, M., Kraus, S., ve Jensen, S. H. (2014). Exploring Relationships Among Proactiveness, Risk-taking and Innovation Output in Family and Non-family Firms. Creativity and Innovation Management, 23(2), 199-210.

Croci, E., Doukas, J. A., ve Gonenc, H. (2011). Family Control and Financing Decisions. European Financial Management, 17(5), 860-897.

Daryanto A. (2018) SPSS Heterogeneity Macro. https://sites.google.com/site/ahmaddaryanto/scripts/Heterogeneity-test (28.05.2019).

Dess, G. G., Lumpkin, G. T., ve Covin, J. G. (1997). Entrepreneurial Strategy Making and Firm Performance: Tests of Contingency and Configurational Models. Strategic management journal, 18(9), 677-695.

Donckels, R., ve Fröhlich, E. (1991). Are Family Businesses Really Different? European Experiences from STRATOS. Family Business Review, 4(2), 149-160.

Edelig A. ve Himine J. (2018). Entreprenuerial Orientation and Small Organizations. https://familybusiness.org/content/the-family-way-how-entrepreneurial-values-help-b (28.05.2019)

Galván, R. S., Martínez, A. B., ve Rahman, M. H. (2017). Impact of Family Business on Economic Development: A Study of Spain's Family-owned Supermarkets. Journal of Business and Economics, 5(12), 243-259.

Grace-Martin, K. (2008). Can Likert Scale Data Ever be Continuous. Article Alley.

Hernández-Perlines, F., Moreno-García, J., ve Yáñez-Araque, B. (2017). Family Firm Performance: The Influence of Entrepreneurial Orientation and Absorptive Capacity. Psychology \& Marketing, 34(11), 1057-1068.

Hisarcıklığlu, R. (2019). TOBB Başkanı Hisarcıklığlu: Ekonomik Alanda İstiklal Mücadelesi Veriyoruz.

http://www.hurriyet.com.tr/gundem/tobb-baskani-hisarciklioglu-ekonomik-alanda-istikl al-mucadelesi-veriyoruz-41218648 (21.05.2019)

John, K., Litov, L., ve Yeung, B. (2008). Corporate Governance and Risk-taking. The journal of finance, 634, 1679-1728. 
Kallmuenzer, A., Strobl, A., ve Peters, M. (2018). Tweaking the Entrepreneurial Orientation-Performance Relationship in Family Firms: The Effect of Control Mechanisms and Family-related Goals. Review of Managerial Science, 12(4), 855-883.

Karpuzoğlu, E. (2004). Büyüyen ve Gelişen Aile Şirketlerinde Kurumsallaşma, İstanbul: Hayat Yayınları, 4. Bask1, 2004.

Kaya, N. (2006). The İmpact of Human Resource Management Practices and Corporate Entrepreneurship on Firm Performance: Evidence From Turkish Firms. The International Journal of Human Resource Management, 17(12), 2074-2090.

Kobal, K. E. S. (2014). Aile İşletmelerinde Kurumsallaşma Sürecinde İkinci Kuşağın Yaşadığı Sorunlar Üzerine Bir Araştırma.

Köylü Gölcü, F. (2018). Aile İşletmeleri, Aile İşletmelerinde Karşılaşılan Yönetim ve Organizasyon Sorunları: Denizli örneği.

Kraiczy, N. D., Hack, A., ve Kellermanns, F. W. (2014). New Product Portfolio Performance in Family Firms. Journal of Business Research, 67(6), 1065-1073.

Kuratko, D. F., Ireland, R. D., ve Hornsby, J. S. (2001). Improving Firm Performance Through Entrepreneurial Actions: Acordia's Corporate Entrepreneurship Strategy. Academy of Management Perspectives, 15(4), 60-71.

Laforet, S. (2013). Innovation Characteristics of Young and Old Family-Owned Businesses. Journal of Small Business and Enterprise Development, 20(1), 204-224.

Leach, P. (1990). Managing the Family Business in the UK. London: Stoy Hayward.

Lee, J. (2006). Family firm performance: Further evidence. Family Business Review, 19(2), 103-114.

Lee, K., Makri, M., ve Scandura, T. (2018). The Effect of Psychological Ownership on Corporate Entrepreneurship: Comparisons Between Family and Nonfamily Top Management Team Members. Family Business Review, 0894486518785847.

Lee, T., ve Chu, W. (2017). The Relationship Between Entrepreneurial Orientation and Firm Performance: Influence of Family Governance. Journal of Family Business Strategy, 8(4), 213-223.

Lee, Y. G., ve Marshall, M. I. (2013). Goal Orientation and Performance of Family Businesses. Journal of family and Economic Issues, 34(3), 265-274.

López-Fernández, M. C., Serrano-Bedia, A. M., ve Pérez-Pérez, M. (2016). Entrepreneurship and Family Firm Research: A Bibliometric Analysis of an Emerging Field. Journal of Small Business Management, 54(2), 622-639.

Lyon, D. W., Lumpkin, G. T., ve Dess, G. G. (2000). Enhancing Entrepreneurial Orientation Research: Operationalizing and Measuring a Key Strategic Decision Making Process. Journal of management, 26(5), 1055-1085.

Martínez, A. B., Galván, R. S., ve Palacios, T. M. B. (2016). An Empirical Study About Knowledge Transfer, Entrepreneurial Orientation and Performance in Family Firms. European Journal of International Management, 10(5), 534-557.

Masulis, R. W., Pham, P. K., ve Zein, J. (2011). Family Business Groups Around the World: Financing Advantages, Control Motivations, and Organizational Choices. The Review of Financial Studies, 24(11), 3556-3600.

Memili, E., Eddleston, K. A., Kellermanns, F. W., Zellweger, T. M., ve Barnett, T. (2010). The Critical Path to Family Firm Success Through Entrepreneurial Risk Taking and İmage. Journal of Family Business Strategy, 1(4), 200-209.

Memili, E., K. A. Eddleston, F. W. Kellermanns, T. M. Zellweger, ve T. Barnett (2010). The Critical Path to Family Firm Success through Entrepreneurial Risk Taking and Image, Journal of Family Business Strategy 1(4), 200-209.

Miller, D. (1983). The Correlates of Entrepreneurship in Three Types of Firms. Management science, 29(7), 770-791.

Miller, D. (1983). The Correlates of Entrepreneurship In Three Types of Firms. Management Science 29(7):770-791. 
Miller, D., ve Le Breton-Miller, I. (2011). Governance, Social Identity, and Entrepreneurial Orientation In Closely Held Public Companies. Entrepreneurship Theory and practice, 35(5), 1051-1076.

Miller, S. P. (2015). Developing Next-generation Leadership Talent in Family Businesses: The Family Effect (Doctoral dissertation, Case Western Reserve University).

Minichilli, A., Brogi, M., ve Calabrò, A. (2016). Weathering the Storm: Family Ownership, Governance, and Performance Through the Financial and Economic Crisis. Corporate Governance: An International Review, 24(6), 552-568.

Naldi, L., Nordqvist, M., Sjöberg, K., ve Wiklund, J. (2007). Entrepreneurial Orientation, Risk Taking, and Performance in Family Firms. Family business review, 20(1), 33-47.

Peters, M., ve Kallmuenzer, A. (2018). Entrepreneurial Orientation in Family Firms: The Case of the Hospitality Industry. Current Issues in Tourism, 21(1), 21-40.

Randolph, R. V., Li, Z., ve Daspit, J. J. (2017). Toward a Typology of Family Firm Corporate Entrepreneurship. Journal of Small Business Management, 55(4), 530-546.

Sabanc1, (2017). Türkiye'deki İşletmelerin Yüzde 95'i Aile Şirketi. https://www.cnnturk.com/ekonomi/turkiyedeki-isletmelerin-yuzde-95i-aile-sirketi (21.05.2019)

Salvato, C., Chirico, F., Melin, L., ve Seidl, D. (2019). Coupling Family Business Research with Organization Studies: Interpretations, Issues, and Insights. Organization Studies.

Salvato, C., F. Chirico, ve P. Sharma (2010). "A Farewell to the Business: Championing Exit and Continuity in Entrepreneurial Family Firms," Entrepreneurship and Regional Development 22(3/4), 321-348.

Schepers, J., Voordeckers, W., Steijvers, T., ve Laveren, E. (2014). The Entrepreneurial Orientation-Performance Relationship in Private Family Firms: the Moderating Role of Socioemotional Wealth. Small Business Economics, 43(1), 39-55.

Siddiquee, Q., Jain, K., ve Rajan, S. (2015). An Approach to Measure Innovativeness of a Firm. The International Journal of Management, 41, 25-37.

Spriggs, M., Yu, A., Deeds, D., ve Sorenson, R. L. (2013). Too Many Cooks in the Kitchen: Innovative Capacity, Collaborative Network Orientation, and Performance in Small Family Businesses. Family Business Review, 26(1), 32-50.

Templeton, G.F. (2011). "A Two-Step Approach for Transforming Continuous Variables to Normal: Implications and Recommendations for IS Research," Communications of the AIS, Vol. 28, Article 4.

Terjesen, S., Hessels, J., ve Li, D. (2016). Comparative International Entrepreneurship: A Review and Research Agenda. Journal of Management, 42(1), 299-344.

Uhlaner, L. M., Kellermanns, F. W., Eddleston, K. A., ve Hoy, F. (2012). The Entrepreneuring Family: A New Paradigm for Family Business Research.

Uzun, K. (2018). Aile Şirketlerinde Kurumsal Dönüşümün Gerekliliği ve Önemi. https://www2.deloitte.com/content/dam/Deloitte/tr/Documents/risk/aile-sirketlerinde-ku rumsal-donusumun-gerekliligi-ve-onemi.pdf (21.05.2019)

Wales, W., Gupta, V. K., Marino, L., ve Shirokova, G. (2019). Entrepreneurial Orientation: International, Global and Cross-cultural Research. International Small Business Journal, 37(2), 95-104.

Wennberg, K., Wiklund, J., Hellerstedt, K., ve Nordqvist, M. (2011). Implications of Intra-family and External Ownership Transfer of Family Firms: Short-term and Long-term Performance Differences. Strategic Entrepreneurship Journal, 5(4), 352-372.

Yolaç, S., ve Doğan, E. (2011). Küreselleşme Sürecinde Aile İşletmelerinde Yönetim ve Kurumsallaşma. İstanbul Üniversitesi İktisat Fakültesi Mecmuası, 61(2), 83-110.

Zehir, C., Altindag, E., ve Acar, A. Z. (2011). The Effects of Relationship Orientation Through İnnovation Orientation on Firm Performance: An Empirical Study On Turkish Family-Owned Firms. Procedia-Social and Behavioral Sciences, 24, 896-908.

Zellweger, T., ve Sieger, P. (2012). Entrepreneurial Orientation in Long-Lived Family Firms. Small Business Economics, 38(1), 67-84. 


\section{SUMMARY}

Family companies, which are identified/ defined in multiple different ways across literature, are an undeniable economic and social power driving national economies. Coupled with the fact that more than $80 \%$ of the enterprises in the world economy are family owned businesses, they constitute as the backbone of many economies. A similar situation exists in the Turkish economy with $95 \%$ of firms being family owned. Drawing attention in terms of their entrepreneurial characteristics and international success, it is argued that these firms entrepreneurial activities have a positive impact on their financial performance. Turkey's growing role in the world economy and the increasing importance of family firms within economic development has created motivation for this study. This study aims to develop a measurable entrepreneurship orientation model through comparable and objective data. Employing use of a Principal Components Analysis an "Entrepreneurship Orientation Index" was developed. This index, which gives meaningful results when measured empirically, is tested by using Moderated Multiple Regression Analysis in relation to financial performance entrepreneurship orientation in family companies. As a result of the analysis, the firms "innovation, proactivity and risk-taking" entrepreneurship components of listed companies in 2018 BISST Manufacturing Industry were examined. The study indicates that family businesses do not have a moderating role in the current relationship, but that these firms risk taking tendency is higher in comparison to non-family firms. Moreover, it was determined that BIST Manufacturing Industry companies have positive entrepreneurial orientation (43\% of the sample). In addition, the highest entrepreneurship orientation values were seen in the Chemical and Metal Goods sectors. It is also determined that the companies with the lowest entrepreneurship orientation operate in the Other Manufacturing Sector. Regardless of the ownership structure of the companies, it has been found that the research and development expenses and share values of the most entrepreneurial companies are high for these companies, however they have low risk - taking tendencies. As a result of this analysis, it can be said that companies with high entrepreneurship orientation avoid taking risks and making more cautious investment decisions. One limitation of the study is the possibility of having different entrepreneurial attitudes and goals in family businesses in different life cycles. Therefore, in order to improve this study, the life cycle of the sample companies can be examined and the effect of entrepreneurial orientation and current relationship on financial performance can be investigated. By including non-financial variables (for example, corporate social responsibility indicators) to the study, the performance criteria examined can also be expanded. It is hoped that this study will prove beneficial to potential investors when evaluating firms. As entrepreneurial orientation is argued to be a core driver of organizational success, investments and improvements in this area would could aid in setting the firm apart from the competition and increase their competitive advantage. Moreover, it is hoped that the developed "Entrepreneurship Orientation Index" could aid in the empirical measurement of future studies. The current entrepreneurship orientation 
Melissa Cagle \& Ahmet Özen / Girişimcilik Yönelimi ve Finansal Performans İlişkisinin Araştırılmasında Aile Şirketlerinin Moderatör Rolü

literature is argued to contain subjective measurement items that reduce the overall comparability of studies. Thus, the development of similar indexes could be beneficial to researchers. 